\title{
ANALISIS KITAB ADAB AL-MUFRAD KARYA IMAM BUKHARI TENTANG PENDIDIKAN ADAB DAN RELEVANSINYA TERHADAP PENDIDIKAN KARAKTER DI INDONESIA
}

\author{
Nurhadi $^{1} \&$ Alfen Khairi ${ }^{2}$ \\ STAI Al-Azhar Pekanbaru Riau ${ }^{1}$, UIN Sultan Syarif Kasim Riau ${ }^{2}$ \\ alhadijurnal@gmail.com, alfenkhairi@gmail.com
}

\begin{abstract}
Islamic education aims to print students into intellectuals who are both intellectually intelligent and morally good. To achieve these educational goals, the morals and manners of the spirit of education need to be revived. In addition, Islamic education must also isolate the secularliberal view of life that exists in every modern scientific discipline. Such education will give birth to humans who are aware of their responsibilities towards their Lord, understand and carry out their obligations to themselves and others in their society, and strive continuously to develop every aspect of themselves towards advancement as moral human beings. To achieve this goal, the Indonesian government rolled out character education. Character education is expected to be able to balance between the fulfillment of cognitive needs with other needs as mandated by the 2003 National Education System Law. Similarly, Islamic education is already familiar with the concept of etiquette. This study aims to determine the concept of etiquette education according to Imam Bukhari in the book of Adab Al Mufrad and to make it relevant with character education in Indonesia. In this study it was found that the concept of education according to Imam Bukhari includes adab to parents, adab to children, adab to others, adab to Allah, and adab to the prophet Muhammad. This concept of etiquette covers the five pillars of the value of character education in Indonesia and can be used as a foothold in describing the values of education that are being practiced in Indonesia.
\end{abstract}

Keywords: Education, Civilization, Character

\begin{abstract}
Abstrak: Pendidikan Islam bertujuan untuk mencetak peserta didik menjadi manusia yang cerdas secara intelektual dan baik secara akhlak. Untuk mencapai tujuan pendidikan tersebut maka akhlak dan adab yang menjadi ruh pendidikan tersebut perlu dihidupkan kembali. Selain itu, pendidikan Islam juga harus mengisolir pandangan hidup sekuler-liberal yang ada di setiap disiplin ilmu pengetahuan modern saat ini. Pendidikan seperti itu akan melahirkan manusia yang menyadari tanggung jawabnya terhadap Tuhannya, memahami dan melaksanakan kewajiban-kewajibannya kepada dirinya dan yang lain dalam masyarakatnya, serta berupaya terus menerus untuk mengembangkan setiap aspek dari dirinya menuju kemajuan sebagai manusia yang bermoral. Untuk mencapai tujuan tersebut, pemerintah Indonesia menggulirkan pendidikan karakter. Pendidikan karakter diharapkan mampu menyeimbangkan antara pemenuhan kebutuhan kognitif dengan kebutuhan lain sebagaimana diamanatkan UU Sisdiknas tahun 2003. Senada dengan itu, pendidikan Islam sudah mengenal terlebih dahulu konsep adab. Penelitian ini bertujuan untuk mengetahui konsep pendidikan adab menurut Imam Bukhari dalam kitab Adab Al Mufrad dan merelevansikannya dengan
\end{abstract}


pendidikan karakter di Indonesia. Dalam penelitian ini ditemukan bahwa konsep pendidikan adab menurut Imam Bukhari mencakup adab kepada orang tua, adab kepada anak, adab kepada sesama, adab kepada Allah swt, dan adab kepada nabi Muhammad saw. Konsep adab tersebut tersebut mencakup lima pilar nilai pendidikan karakter di Indonesia dan bisa dijadikan dasar pijakan dalam menjabarkan nilai-nilai pendidikan yang sedang dipraktekkan di Indonesia.

Kata Kunci: Pendidikan, Adab, Karakter

\section{PENDAHULUAN}

Tujuan pendidikan dalam ajaran Islam bukan sekedar mencetak peserta didik menjadi manusia yang cerdas secara intelektual namun juga bertujuan untuk mencetak generasi yang baik secara akhlak. Tafsir mengemukakan bahwa tujuan pendidikan Islam menurut Muhammad 'Athiya Al Abrasyi adalah manusia yang berakhlak mulia (Ahmad Tafsir, 2013, 16). Maka setiap lembaga pendidikan Islam harus melahirkan generasi yang berakhlak dan beradab. Untuk mencapai tujuan pendidikan tersebut maka akhlak dan adab yang menjadi ruh pendidikan tersebut perlu dihidupkan kembali (Ahmad Tafsir, 2013, 16).

Pendidikan Islam juga harus mengisolir pandangan hidup sekuler-liberal yang ada di setiap disiplin ilmu pengetahuan modern saat ini. Ketika perubahan secara islami (dalam kurikulum, lingkungan, visi, dan misi) terjadi, pendidikan Islam akan membebaskan manusia dari kehidupan sekuler menuju kehidupan yang berlandaskan ajaran Islam. Dari pendidikan seperti itulah manusia yang baik dan beradap akan lahir. Individu-individu seperti itu adalah manusia yang menyadari tanggung jawabnya terhadap Tuhannya, memahami dan melaksanakan kewajiban-kewajibannya kepada dirinya dan yang lain dalam masyarakatnya, serta berupaya terus menerus untuk mengembangkan setiap aspek dari dirinya menuju kemajuan sebagai manusia yang bermoral (Syarif Hidayat, 2018, 2).

Pendidikan dalam Islam dimulai dengan mempelajari adab, sebelum menimba ilmu itu sendiri. Allah swt berfirman "Wahai Musa, sunggub aku adalab Rabbmu, maka lepaskanlab kedua terompahmu. Karena sesunggubnya engkau berada di lembah yang suci, Tuwa" (Departemen Agama RI, 2012, 312). Setelah perintah menanggalkan alas kaki untuk menghormati tempat yang disucikan Allah swt, barulah ilmu itu disampaikan kepada 
nabi Musa. Dalam ayat selanjutnya, Allah swt berfirman, "Maka dengarkanlah apa yang diwabyukan kepadamu" (Departemen Agama RI, 2012, 313).

Adab ini telah dicontohkan sahabat nabi tatkala menerima ilmu dari Rasulullah saw. Sahabat Abu Sa'id Al Khudri berkata, "Ketika kami sedang duduk-duduk di masjid, Rasulullah saw tiba-tiba keluar dan duduk bersama kami. Maka, seakan-akan di atas kepala kami ada seekor burung, sehingga tidak ada satupun dari kami yang berbicara" (Abu Abdillah al-Bukhari, 2012, 10). Adab dalam tradisi ilmu ulama salaf bukanlah sekedar selingan yang diajari beberapa jam dalam sepekan. Porsi pelajaran adab bahkan lebih besar dari materi ilmu yang dipelajari. Ibnu Mubarak berkata, "Kami mempelajari masalab adab selama 30 tahun, sedangkan kami mempelajari ilmu selama 20 tahun”. Beliau juga berkata, "Hampir saja adab menjadi dua pertiga ilmu” (Ibnu al-Jauzy, 1985, 145).

Begitu perhatiannya ulama salaf terhadap adab kepada mata air ilmu mereka hingga murid Imam Syafi'i, Ar Rabi' bin sulaiman, berkata, "Saya tidak berani meneguk air ketika Asy Syafi'i melihatku karena segan kepada beliau". Imam Adz Dzahabi juga menyebutkan bahwa tidak ada seorangpun berbicara di majelis Abdurrahman bin Mahdi, berdiri, atau meruncingkan alat tulis, juga tidak ada satupun yang tersenyum (Ibnu al-Jauzy, 1985, 3671). Pentingnya adab juga mendapatkan perhatian khusus dari KH. Hasyim Asy'ari pendiri Nahdlatul Ulama dalam bukunya Adab Al Alim wal Muta'allim, dikisahkan bahwa suatu ketika Imam Syafi'i pernah ditanya seseorang, "Sejauh manakah perhatianmu terhadap adab?" Beliau menjawab "Setiap kalau telingaku menyimak suatu pengajaran budi pekerti meski hanya satu buruf, maka selurub organ tububku akan ikut merasakan (mendengarnya) seolah-olah setiap organ itu memiliki alat pendengaran (telinga)” (Hasyim Asy'ari, 1415 H, 9).

Mengingat pentingnya adab bagi setiap pribadi muslim sebagaimana yang telah dicontohkan oleh nabi, para sahabat, dan tabi'in maka untuk mendapatkan adab yang dimaksud perlu menggali dari sumber landasan Islam itu sendiri, yaitu Al-Qur'an dan Hadis (Ulil Amri Syafri, 2011, 163). Terlebih tentang adab seorang hamba kepada Sang Pencipta dimana adab ini yang menjadi tujuan utama dalam kehidupan seorang muslim. Dalam Islam, pembinanaan akhlak atau adab merupakan bagian yang integral dalam dunia pendidikan karena menjadi tujuan yang dituju, yaitu menciptakan manusia yang berakhlak, beradab dan bertakwa melalui ilmu pengetahuan, keterampilan, dan bersikap sesuai nilai-nilai Islam (Ulil Amri Syafri, 2012, 68-69). 
Adab menjadi permasalahan yang mendasar bagi pendidikan di Indonesia. Berbagai masalah mencuat akhir-akhir ini di tengah masyarakat kita, baik itu masalahmasalah sosial, politik, ekonomi, maupun masalah kemasyarakatan lainnya seperti kasus-kasus kekerasan dalam rumah tangga, tauran antar pelajar, korupsi, pornografi dan pornoaksi, serta kekerasan antar umat beragama apabila ditinjau dari sudut pandang pendidikan memperlihatkan perlunya penekanan adab dalam sistem pendidikan nasional kita untuk membentuk masyarakat yang selain memiliki kecerdasan dan keterampilan juga memiliki spritualitas, pengendalian diri, kepribadian, dan akhlak mulia. Indonesia saat ini sedang menghadapi krisis multidimensi yang berkepanjangan. Krisis multidimensi tersebut hakikatnya berakar dari menurunnya kualitas moral bangsa. Adapun tanda-tanda penurunan kualitas moral diantaranya membudayanya praktek korupsi, sering terjadi konflik (antaretnis, agama, politisi, remaja, dsb), angka kriminalitas yang semakin menanjak, dan penurunan etos kerja (Ratna Megawangi, 2004, 4).

Salah satu solusi yang diambil pemerintah Indonesia saat ini adalah dengan menggulirkan pendidikan karakter. Sejak pertama kali dicanangkan oleh Menteri Pendidikan Nasional pada peringatan hari pendidikan Nasional pada 2010 lalu, pendidikan karakter diharapkan mampu menyeimbangkan antara pemenuhan kebutuhan kognitif dengan kebutuhan lain sebagaimana diamanatkan UU Sisdiknas tahun 2003. Terdapat lima hal pokok dalam penyelenggaraan pendidikan karakter, yaitu: 1) Membentuk manusia Indonesia yang bermoral, 2) Membentuk manusia Indonesia yang cerdas dan rasional, 3) Membentuk manusia Indonesia yang inovatif dan suka bekerja keras, 4) Membentuk manusia Indonesia yang optimis dan percaya diri, dan 5) Membentuk manusia Indonesia yang berjiwa patriot (Indra Fajar Nurdin, 2015, 159). Syed Muhammad Naquib Al Attas mengatakan bahwa akar dari segala permasalahan atau krisis yang mendera suatu bangsa dewasa ini, bermuara pada hilangnya adab (the loss of adab). Al Attas merujuk pada hilangnya disiplin-disiplin raga, fikiran dan jiwa. Disiplin menuntut pengenalan dan pengakuan atas tempat yang tepat bagi seseorang dalam hubungannya dengan diri, masyarakat, dan umatnya; pengenalan dan pengakuan atas tempat seseorang yang semsestinya dalam hubungannya dengan kemampuan dan kekuatan jasmani, intelektual, dan spiritual seseorang (Syed Muhammad Naquib al-Attas, 2011, 129). 
Melihat pentingnya adab yang menjadi kebutuhan dalam kehidupan bermasyarakat, dan permasalahan-permasalahan serta kesenjangan sosial yang terjadi saat ini yang disebabkan oleh menurunnya moralitas, dan gagalnya sistem pendidikan nasional dalam mengatasi problem tersebut, maka sudah seharusnya kita kembali merujuk kepada generasi terbaik dari umat ini, yaitu generasi sahabat dan tabi'in yang bersumber dari Al-Qur'an dan hadis. Untuk memfokuskan penelitian ini, maka penulis memilih kitab Adab Al Mufrad karya Imam Bukhari yang berisi kumpulan hadis-hadis adab (adab kepada orang tua, adab kepada anak, adab kepada sesama, adab kepada nabi, dan adab kepada Allah swt). Imam Bukhari adalah Salah satu ulama Islam yang memberikan perhatian khusus terhadap permasalahan hadis. Beliau hidup pada tahun 194-256 H, seorang ulama hadis yang termasyhur diantara para ahli hadis dari dulu sampai sekarang. Hadis-hadisnya memiliki derajat yang tinggi, sebagian menyebutnya denga Amir Al-Mukminin fi Al Hadis (Pemimpin orang-orang beriman dalam ilmu hadis (Zainal Abidin Ahmad, 1975, 99).

Perhatian khusus yang diberikan oleh Imam Bukhari terhadap permasalahan adab adalah dengan mengumpulkan hadis-hadis yang berkaitan dengan akhlak Rasulullah berjumlah 245 hadis yang saw dalam karya beliau yang monumental Shabih Al Bukhari. Kemudian Imam Bukhari yang menghimpun berbagai riwayat seputar adab dan akhlak mulia yang berasal dari Rasulullah saw, para sahabat radbiyallabu anbum, dan juga para ulama generasi tabi'in dan atba' at tabi'in dalam kitab Adab Al Mufrad. Terdapat 1322 hadis yang terbagi kepada 643 judul bab. Jumlah hadis di dalam setiap judul babnya tidak sama, ada yang terdiri dari satu, dua hingga lima buah hadis. Kitab ini membahas seputar adab kepada kedua orang tua, adab kepada anak, adab silaturrahim, adab bertetangga, adab kepada anak yatim, dan lain (Ihsan Muhidin, dan Ulil Amri Syafri, 2016, 3-4).

Berdasarkan latar belakang yang telah dikemukakan sebelumnya, permasalahan dari penelitian ini dapat dirumuskan sebagai berikut: a). Bagaimana konsep pendidikan adab dalam kitab Adab Al-Mufrad karya Imam Bukhari?; b). Bagaimana relevansi pendidikan adab dalam kitab Adab Al-Mufrad karya Imam Bukhari terhadap pendidikan karakter di Indonesia? 


\section{KAJIAN PUSTAKA}

\section{Pendidikan Adab}

Pendidikan secara etimologis, berasal dari kata Yunani "pedagogic" yang terdiri atas kata "pais" yang berarti "anak" dan kata "ago" yang berarti "aku membimbing". Jadi pedagogic berarti aku membimbing anak. Purwanto menyatakan bahwa pendidikan berarti segala usaha orang dewasa dalam pergaulannya dengan anak-anak untuk memimpin perkembangan jasmani dan rohaninya kearah kedewasaan (Ngalim, Purwanto, 1986, 11).

Menurut UU Sisdiknas Pasal 1 No. 20 Tahun 2003, pendidikan diartikan sebagai: "Usaha sadar dan terencana untuk mewujudkan suasana belajar dan proses pembelajaran agar peserta didik secara aktif mengembangkan potensi dirinya untuk memiliki kekuatan spiritual keagamaan, pengendalian diri, kepribadian, kecerdasan, akhlak mulia serta keterampilan yang diperlukan dirinya, masyarakat, bangsa dan Negara (Undang-Undang Republik Indonesia No. 20 Tahun 2003, 2007, 2).

Pendidikan dalam konteks Islam pada umumnya mengacu kepada term tarbiyah, ta'lim, dan ta'dib. Dari ketiga istilah tersebut, term yang paling populer digunakan dalam praktek pendidikan Islam adalah term tarbiyah. Sedangkan term ta'dib dan ta'lim jarang sekali digunakan. Padahal kedua istilah tersebut telah digunakan sejak awal pertumbuhan pendidikan Islam (Samsul Nizar, 2002, 25).

Istilah ta'dib atau adab mempunyai arti dasar "undangan kepada suatu perjamuan" Ibnu Mandzur juga menyebutkan ungkapan "addabahu fataaddaba” berarti “allamabu” (mendidiknya) (Ibnu Mandzur, 1990, 206). Gagasan ke suatu perjamuan mengisyaratkan tuan rumah adalah orang yang mulia dan banyak orang hadir, dan bahwasanya orang yang hadir adalah orang-orang yang menurut perkiraan tuan rumah pantas mendapatkan kehormatan untuk diundang dan, oleh karena itu, mereka adalah orang-orang bermutu dan berpendidikan tinggi yang diharapkan bisa bertingkah laku sesuai dengan keadaan, baik dalam berbicara, bertindak, maupun etiket (Syed Muhammad Naquib al-Attas, 1996, 56-57).

Menurut Dedeng Rosidin, adab pada masa kejayaan Islam digunakan dalam makna yang sangat umum, yaitu bagi semua ilmu pengetahuan yang dihasilkan oleh akal baik langsung berhubungan dengan Islam maupun yang tidak langsung 
kemudian berkembang maknanya menjadi budi pekerti yang baik, perilaku terpuji dan sopan santun. Pada akhirnya makna adab menunujukkan arti: 1) mengajar sehingga orang yang belajar mempunyai budi pekerti yang baik, 2) mendidik jiwa dan akhlak, 3) melatih berdisiplin (Dedeng Rosidin, 2003, 169).

Dari uraian pengertian pendidikan dan adab di atas pada dasarnya kedua kata tersebut mempunyai arti yang sama karena adab atau ta'dib merupakan salah satu term pendidikan dalam Islam. Pendidikan adab secara sederhana adalah suatu upaya bimbingan yang dilakukan oleh generasi tua terhadap generasi muda supaya menjadi orang-orang bermutu dan berpendidikan tinggi yang diharapkan bisa bertingkah laku sesuai dengan keadaan, baik dalam berbicara dan bertindak.

\section{Pendidikan Karakter}

Karakter secara etimologi berasal bahasa Latin "kharakter", "kharassein", "kharax", yang berarti membuat tajam dan membuat dalam (Abdul Majid dan Dian Andayani, 2011, 11). Secara terminologi, karakter dimaknai sebagai cara berpikir dan berprilaku yang khas tiap individu untuk hidup dan bekerja sama, baik dalam lingkup keluarga, masyarakat, bangsa, dan negara. Karakter dapat dianggap sebagai nilai-nilai prilaku manusia yang berhubungan dengan Tuhan Yang Maha Esa, diri sendiri, sesama manusia. Lingkungan dan kebangsaan yang terwujud dalam pikiran, perkataan, dan perbuatan berdasarkan norma-norma agama, hukum, tata krama, budaya, adat-istiadat, dan estetika. Karakter adalah perilaku yang tampak dalam kehidupan sehari-hari baik dalam bersikap maupun dalam berindak (Muchlas Samani dan Hariyanto, 2011, 41).

Lickona mendefinisikan orang yang berkarakter sebagai sifat alami seseorang dalam merespons situasi secara bermoral yang dimanifestasikan dalam tindakan nyata melalui tingkah laku yang baik, jujur, bertanggung jawab, menghormati orang lain dan karakter mulia lainnya (Thomas Lickona, t.th, 12-22). Sedangkan menurut Scerenko, pendidikan karakter dapat dimaknai sebagai upaya yang sungguh-sungguh dengan cara di mana ciri kepribadian positif dikembangkan, didorong, dan diberdayakan melalui keteladanan, kajian (sejarah dan biografi para bijak dan pemikir besar), serta 
praktek emulasi (usaha yang maksimal untuk mewujudkan hikmah dari apa-apa yang diamati dan dipelajari) (Muchlas Samani dan Hariyanto, 2011, 44).

Berdasarkan pusat kurikulum definisi pendidikan karakter adalah sebagai berikut: "Pendidikan karakter bangsa dapat dimaknai sebagai pendidikan yang mengembangkan nilai-nilai budaya dan karakter bangsa pada diri peserta didik sehingga mereka memiliki nilai dan karakter sebagai karakter dirinya, menerapkan nilai-nilai tersebut dalam kehidupan dirinya, sebagai anggota masyarakat, dan warga negara yang religius, nasionalis, produktif, dan kreatif' (Sri Wahyuni dan Abd. Syukur Ibrahim, 2012, 23).

Menurut dokumen Desain Induk Pendidikan Karakter terbitan Kementrian Pendidikan Nasional Pendidikan Karakter didefinisikan sebagai pendidikan nilai, pendidikan Budi pekerti, pendidikan moral, pendidikan watak, yang bertujuan mengembangkan kemampuan peserta didik untuk mengambil keputusan baik, memelihara apa yang baik, dan mewujudkan kebaikan ittu dalam kehidupan seharihari dengan sepenuh hati (M. Ali David, Nanang Susilo, 2015, 8).

Dari berbagai pengertian pendidikan karakter di atas, maka pendidikan karakter dapat dimaknai sebagai usaha sadar dan terencana dalam menginternalisasikan nilainilai karakter sehingga karakter tersebut dapat dimengerti, dihayati dan dilaksanakan dalam kehidupan sehari-hari oleh peserta didik.

\section{METODE PENELITIAN}

Penelitian ini menggunakan data penelitian kualitatif dengan menggunakan metode konten analisis dengan menggunakan teknik analisis melalui studi kepustakaan. Menurut Keirl dan Miller yang dimaksud dengan penelitian kualitatif adalah tradisi tertentu dalam ilmu pengetahuan sosial yang secara fundamental bergantung pada pengamatan manusia terhadap kawasannya sendiri, dan berhubungan denga orang-orang tersebut dalam bahasanya dan istilahnya. Dan pendekatan yang digunakan yakni pendekatan ekspresif (berhubungan dengan pengarang), pendekatan objektif (berhubungan dengan teks), pendekatan mimetic (berhubungan dengan kesemestaan), dan pendekatan pragmatik (berhubungan dengan resepsi pembaca terhadap teks) (Suwardi Endraswara, 2003, 9). 
Sumber data pada penelitian ini adalah literatur-literatur yang berkaitan. Sumber primer pada penelitian ini adalah kitab karya Imam Bukhari yaitu: Kitab Adab Al Mufrad yang diterbitkan oleh Dar Al-Hadis Kairo tahun 2005 dan ditahqiq oleh Farid Abdul Aziz Al jindiy dan dibantu oleh tahqiq Fuad Abdul Baqi. Dan yang menjadi sumber data sekunder adalah syarah dari kitab Adab Al-Mufrad dan Shabih Bukhari, dan buku-buku yang berkaitan dengan pendidikan adab dan pendidikan karakter.

Penulis melakukan beberapa langkah penelitian, pertama mengidentifikasi pendidikan adab dalam karya Imam Bukhari dalam kitab Adab Al Mufrad. Kedua merumuskan secara sistematis pendidikan adab dalam karya Imam Bukhari dalam kitab Adab Al-Mufrad. Ketiga melakukan analisis terhadap pendidikan adab dalam karya Imam Bukhari dalam kitab Adab Al-Mufrad dengan kitab-kitab yang berkaitan dengan adab lalu diklasifikasikan dan kedalam kategorisasi. Keempat, merelevansikan konsep pendidikan adab dalam kitab Adab Al-Mufrad karya Imam Bukhari dengan pilar-pilar pendidikan karakter di Indonesia. Kelima. menarik kesimpulan setelah dianalisis secara mendalam dan menyeluruh.

\section{PEMBAHASAN}

\section{Konsep Pendidikan Adab dalam Kitab Adab Al-Mufrad Imam Bukhari}

Pendidikan adab menurut Imam Bukhari tidak beliau sebutkan secara langsung dalam kitab-kitabnya. Namun defenisi pendidikan adab itu bisa kita fahami dari karya beliau, yaitu Shabih Bukhari dan Adab Al-Mufrad yang mana kitab-kitab ini beliau susun dengan bab-bab yang beliau tetapkan sendiri dan mengelompokkan hadis-hadis tersebut dalam suatu tema pembahasan adab. Ibnu Hajar Al-Asqalani menjelaskan pendidikan adab yang ada dalam kitab Shahih Bukhari, adab mencakup hal-hal yang terpuji dalam ucapan dan perbuatan, memiliki akhlak yang mulia, konsisten bersama hal-hal yang baik, menghormati yang lebih tua dan kasih sayang pada yang lebih muda (Ibnu Hajar al Atsqalani, 2003, 166).

Dalam kitab Adab Al-Mufrad terdapat banyak adab yang sudah hilang dari diri manusia, padahal sangat penting untuk dipraktekkan dalam kehidupan sehari-hari untuk menjadi seorang yang beradab. Dalam muqaddimah muhaqqiq Adab Al-Mufrad 
bahwa di dalam kitab ini terkumpul adab-adab islami yang harus dimiliki setiap pribadi muslim. Seperti, berbuat baik kepada kedua orang tua, menyambung tali silaturrahim, memberikan hak-hak tetangga, memelihara anak yatim, saling memaafkan dan berlapang dada, berakhlak baik, saling berkunjung, menjenguk orang sakit, sifat malu, adab berdoa, memuliakan tamu, adab meminta izin, amanah, dan adab-adab lainnya yang harus diperhatikan (Husain bin Audah, 2003, 6).

\section{Adab kepada orang tua}

Imam Bukhari memulai pembahasan dalam kitab Adab Al Mufrad dengan surat Al-Ankabut ayat 8 tentang perintah Allah swt untuk berbuat baik kepada kedua orang tua.

$$
\text { وَوَصَيْنَا الإِنْسَانَ بِوَالِدَيْهِ حُسْنًَا }
$$

"Dan kami wajibkan kepada manusia agar (berbuat) kebaikan kepada kedua orang tuanya." (QS. Al Ankabut: 8) (Departemen Agama RI, 2012, 397).

Ayat ini turun pada permasalahan Sa'ad bin Abi Waqqash ra, yang terkenal sangat berbakti kepada ibunya. Ketika dia masuk Islam maka ibunya berkata: "Wahai Sa'ad, apa yang telah kamu lakukan? Kamu harus meninggalkan agama barumu itu, atau saya tidak akan makan dan minum, dan saya tidak akan berteduh dari terik matahari sampai saya mati”. Kemudian ibu Sa'ad bertahan dengan keadaannya itu selama beberapa hari sampai orang-orang pada waktu itu memanggil Sa'ad si pembunuh ibunya. Sa'ad berkata: "Demi Allah, wabai ibuku seandainya ibu memiliki seratus nyawa dan keluar satu persatu saya tidak akan meninggalkan agama saya ini”. Maka turunlah ayat ini, dan surat Luqman ayat 14, dan surat Al-Ahqaf ayat 15. Ayat ini telah memutuskan untuk mewajibkan berbuat baik kepada kedua orang tua dan untuk taat kepada keduanya walaupun keduanya orang kafir, kecuali apabila keduanya memerintahkan kepada kesyirikan maka wajib untuk tidak menaati keduanya (Badru Ad Din, 2001, 127).

Imam Bukhari menyebutkan hadis-hadis bagaimana seorang anak harus berinteraksi dengan kedua orang tuanya. Beliau memulainya dengan ayat Al-Qur'an yang mengatakan bahwa berbakti kepada orang tua adalah perintah Allah secara 
langsung. Betapa besarnya jasa kedua orang tua kepada anak, sampai-sampai di dalam Al-Qur'an Allah swt memerintahkan untuk bersyukur kepada-Nya kemudian diikuti langsung setelahnya untuk bersyukur kepada kedua orang tua. Jasa orang tua tidak akan pernah bisa ditebus oleh anaknya. Dikisahkan bahwa Ibnu Umar sedang melakukan thawaf bersama seorang pemuda dari Yaman sambil menggendong ibunya, kemudian pemuda itu berkata kepada Ibnu Umar "Wahai Ibnu Umar, apakah dengan cara seperti ini saya telah membalas kebaikan ibu ku?" Ibnu Umar menjawab, "Belum, babkan tidak sebanding dengan satu tarikan nafasnya saat melabirkanmu" (Abu Abdillah al-Bukhari, 2012, 12).

Allah swt sangat menegaskan untuk berbakti kepada orang tua. Maka seorang anak harus berhati-hati ketika berinteraksi dengan orang tua, penuh hormat dan ta'zhim, serta selalu merendahkan diri dan melembutkan pembicaraan dengan mereka. Di dalam Al-Qur'an Allah swt dengan jelas melarang untuk berkata "ab" kepada orang tua, apalagi sampai mencaci orang tua. Durhaka kepada orang tua merupakan dosa besar sebagaimana yang telah nabi jelaskan dalam hadis-hadisnya. Nabi saw mengungkapkan bahwa dosa durhaka kepada orang tua harus dipercepat siksaannya bagi pelakunya di dunia dan siksanya di akhirat. Nabi Muhammad saw mengajarkan agar tetap ta'at dan berbakti kepada orang tua walaupun orang tua sering menzhalimi anaknya. Menta'ati semua perintah kedua orang tua adalah suatu hal yang mutlak kecuali dalam kemaksiatan dan kemusyrikan. Membuat orang tua menangis merupakan suatu kedurhakaan dan termasuk ke dalam golongan dosa besar (Muhammad Al-Khauli, 1423 H, 44).

Berbakti kepada kedua orang tua bisa menambah panjang umur, sebagaimana sabda nabi, "Siapa yang berbakti kepada kedua orang tuanya, maka beruntunglah dia dan Allah tambabkan umurnya". Berbakti kepada kedua orang tua merupakan salah satu kunci untuk masuk surga. Orang yang bertemu kedua orang tuanya dan tidak masuk surga karena tidak berbakti kepada kedua orang tuanya adalah orang yang sangat merugi di dunia dan akhirat. Orang tua yang musyrik tetap berhak mendapatkan bakti dari anaknya yang muslim, dan mendapat pelayanan yang baik dari anaknya. Akan tetapi orang tua yang musyrik tidak bisa dimintak ampunkan atas dosa-dosa kesyirikannya oleh anaknya yang muslim, berdasarkan firman Allah swt "Tidak pantas 
bagi nabi dan orang-orang beriman memohon ampun (kepada Allah) bagi orang-orang musyrik, sekalipun orang-orang itu kaum kerabatnya, setelah jelas bagi mereka bahwa orang-orang musyrik itu penghuni neraka jahannam” (Departemen Agama RI, 2012, 205). Seorang anak yang muslim wajib mendoakan orang tuanya yang musyrik supaya mendapat hidayah untuk memeluk Islam. Abu Hurairah ra mempunyai seorang ibu yang beragama Nasrani dan beliau ingin ibunya untuk masuk Islam. Beliau datang kepada nabi saw dan minta ibunya didoakan supaya mendapat hidayah dan masuk Islam, kemudian nabi mendoaakan ibunya. Kemudian Abu Hurairah pulang dan mendapatkan ibunya telah masuk Islam (Yusuf Khatir As Suri, 2004, 16).

Berbakti kepada kedua orang tua juga bisa dilakukan setelah mereka meninggal dunia. Ada enam cara berbakti kepada kedua orang tua setelah mereka meninggal dunia. Pertama, mendoakan keduanya. Kedua, banyak meminta ampunan kepada Allah untuk kedua orang tua. Ketiga, memenuhi janji mereka setelah meninggal dunia. Keempat, menjalin hubungan silaturrahim dengan keluarga dekat kedua orang tua yang tidak pernah terjalin sebelumnya. Kelima, memuliakan teman dekatnya dengan menjaga silaturrahim dengan teman-teman ayah dan ibu. Keenam, bersedakah atas nama orang tua yang telah tiada (Abdurrahman Asyayi', 2016, 78).

\section{Adab Kepada Anak}

Imam Bukhari menyusun hadis-hadis adab kepada anak dengan memulai dari kewajiban orang tua dalam memenuhi segala kebutuhan anak. Kebutuhan akan tempat berlindung, kebutuhan akan pengetahuan tentang agama, kebutuhan akan kasih sayang. Kasih sayang terhadap anak bisa diungkapkan dengan cara menggendong anak di atas pundak, mencium anak, merangkul anak, memberi nama anak, mengusap kepala anak, dan memanggil anak dengan panggilan "Wabai anakku". Ketika orang tua telah mencukupi semua kebutuhan anak tersebut maka orang tua berhak untuk mendapatkan surga sesuai hadis di atas (Muhammad ibn Ibrahim, 2002, 51). Berikut adalah hadis-hadis yang dikumpulkan oleh Imam Bukhari tentang hakhak anak yang harus dipebuhi oleh kedua orang tua dalam bentuk adab orang tua kepada anak. 
Hadis No. 78

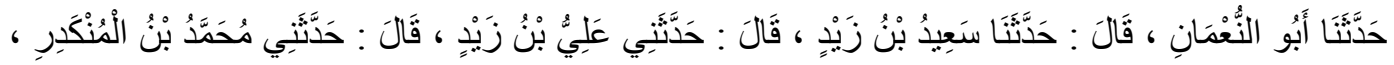

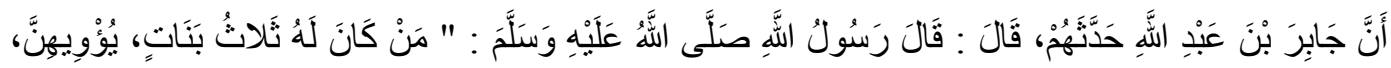

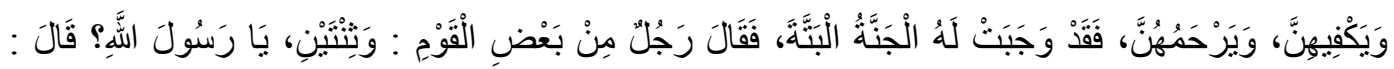

Abu Nu'man menceritakan pada kami: Said bin Zaid menceritakan pada kami: ali bin Zaid mengabariku: Mubammad bin al-Munkadir menceritakan padaku: babwa Jabir Ibnu Abdullah menceritakan kepada mereka seraya berkata, "Rasulullah shallallabu'alaibi wasallam bersabda, "Barang siapa memiliki tiga anak perempuan, memberikan tempat berlindung kepada mereka, mencukupi kebutuban mereka, dan menyayangi mereka, maka wajib baginya surga." Lalu seseorang di antara sebagian kaum itu berkata, "Tuga dua anak perempuan, wahai Rasulullab?" Rasulullah menjawab, "Juga dua anak perempuan" (Abu Abdillah al-Bukhari, 2012, 30). Hasan, di dalam kitab At-Ta'liqu Ar-Raghibu (3/85), Ash-Shahihah (294, 2492).

Hadis ini menunjukkan bahwa seseorang yang memiliki tiga orang anak perempuan, kemudian dia melindungi, mencukupi kebutuhan, dan menyayangi anakanaknya maka dia mendapatkan surga. Anak-anak merupakan tanggung jawab orang tua dalam membesarkan, memberi makan, dan mendidiknya. Dalam hadis ini disebutkan anak perempuan, karena pada zaman jahiliyah ketika seorang ibu melahirkan anak perempuan dianggap sebagai beban dan sebagai aib keluarga. Keadaan ini digambarkan oleh Allah dalam Al-Qur'an 'Dan apabila seseorang dari mereka diberi kabar dengan kelahiran anak perempuan, bitamlah mukanya dan dia sangat marah. Ia menyembunyikan dirinya dari orang banyak, disebabkan buruknya berita yang disampaikan padanya. Apakah dia akan memeliharanya dengan menanggung kehinaan atau menguburnya ke dalam tanah (bidup-hidup). Ketabuilah alangkah buruknya apa yang telah mereka tetapkan itu” (Departemen Agama RI, 2012, 273).

\section{Hadis No. 90}

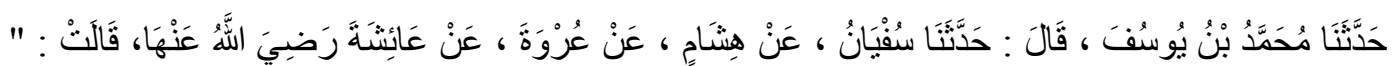

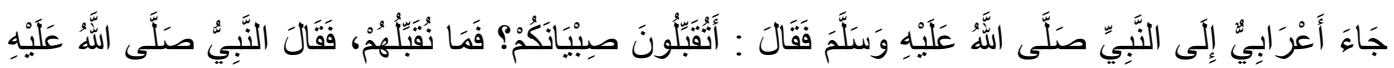

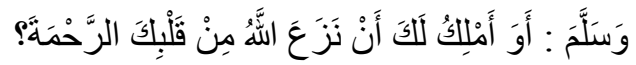


Muhammad bin Yusuf menceritakan pada kami: Sufyan mencertiakan pada kami: Dari Hisyam: Dari Urwab: Dari Aisyah radiallabu'anha, dia berkata: "Orang Arab Badui datang kepada Nabi shallallabu 'alaibi wasallam lalu bertanya, "Apakah kalian mencium anak-anak kalian? kami tidak mencium mereka!” Lalu Nabi shallallabu 'alaibi wasallam bersabda: "Apakah aku kuasa menahan untukemu jikea Allab mencabut kasih sayang dari hatimu?" (Abu Abdillah alBukhari, 2012, 33). Shahih (Bukhari, 78- Kitab Al-Adab, 18- Bab Rahmatul Waladi Taqbiluhu wa Mu'anaqatuhu, Muslim, 43- Kitab Al-Fadha'il hadits 64).

Hadis ini menerangkan tentang keutamaan mencium anak-anak, dan mengoreksi kesalahan sesuai tempat. Mencium anak-anak merupakan suatu bentuk kasih sayang dan kelembutan hati serta menjelaskan hubungan antara zhahir dan bathin seseorang (Abu Abdillah al-Bukhari, 2012, 119). Imam An Nawawi mengatakan bahwa mencium pipi anak kecil adalah wajib, begitu juga mencium tangannya, dan semisalnya atas dasar bentuk kasih sayang dan kelembutan, dan mencintai kelurga terdekat adalah sunnah sama saja laki-laki atau perempuan. Adapun mencium dengan syahwat maka hukumnya haram menurut semua pendapat ulama, sama saja mencium anak kecil ataupun orang dewasa. Akan tetapi hukum-hukum syari'at wajib, sunnah, semestinya harus ada dalilnya, sedangkan An Nawawi tidak mendatangkan satupun dari dalil tersebut (Fadhlullah Al Jilany, 1378 H, 175).

\section{Hadis No. 367}

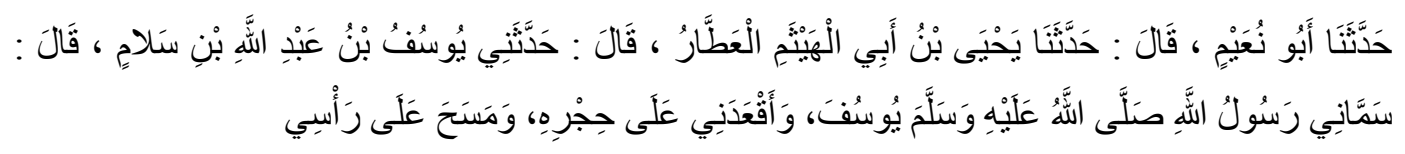

Abu Nuaim menceritakan pada kami: Yabya bin Abu Al-Haitsam Al-Athar menceritakan pada kami: Yusuf ibnu Salam menceritakan padaku: ia berkata, "Rasulullah shallallabu "alaibi wasallam memberi nama kepada saya Yusuf, mendudukekan saya di atas pangkuannya, dan mengusap kepalaku" (Abu Abdillah al-Bukhari, 1375 H, 95). Shahih, sanadnya. (Musnad Ahmad juz 7 hal 6, cet. Pertama)

Hadis ini menjelaskan bahwa disunnahkan seseorang yang berilmu atau orang sholeh untuk mengusap kepala anak-anak dan memberinya nama, sebagaimana yang diisyaratkan oleh Imam Bukhari dalam penulisan bab mengusap kepala anak-anak. Selain mengusap dan memberi nama bayi, Rasulullah juga mengusap dan mendoakan bayi tersebut. Menusap kepala merupakan salah satu cara untuk menunjukkan 
kedekatan batin kepada anak sehingga anak merasa mendapatkan pengayoman dan kasih sayang dari orang tua. Hal ini sangat berarti untuk membesarkan hati mereka dan jauh lebih mahal daripada memberi harta dengan sikap kaku dan tidak peduli (Husain bin Audah, 2003, 485).

\section{Adab Kepada Sesama}

Adab kepada sesama mempunyai ruang lingkup yang sangat luas. Oleh karena itu sebagian besar hadis-hadis yang dikumpulkan oleh Imam Bukhari dalam kitab Adab Al-Mufrad berisi tentang adab kepada sesama. Dari jumlah keseluruhan 1322 hadis yang ada dalam kitab Adab Al-Mufrad, sebanya 1129 hadis, atau 549 bab dari 643 bab membahas tentang adab kepada sesama. Berikut adalah bentuk adab kepada sesama yang ditekankan oleh Imam Bukhari, menjaga silaturrahim dengan keluarga, kerabat, dan saudara-saudara, berbuat baik kepada tetangga dan memberikan hak-hak tetangga, berbuat baik kepada budak, saling memaafkan, saling berbagi,dilarang saling menghina dan memuji karena kedua-duanya menyebabkan kehancuran pada orang yang dihina ataupun dipuji, memuliakan yang lebih tua dan menyayangi yang lebih muda. Termasuk juga kedalam adab kepada sesama makhluk adalah menyayangi binatang, menjenguk orang sakit, menghormati tamu dan memberikan hak-hak tamu, berbicara dengan kata-kata yang baik, optimis dalam kehidupan, mengucapkan salam, dan adab-adab lainnya yang perlu diperhatikan.

\section{Hadis No. 52}

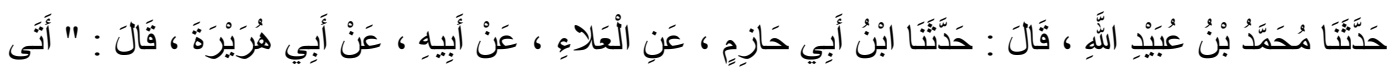

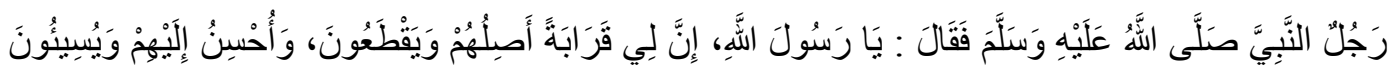

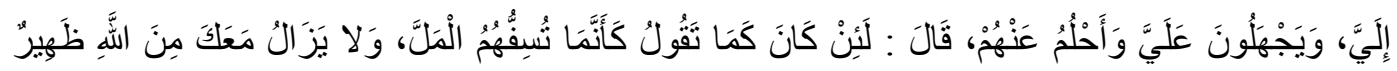

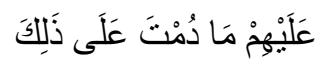

Mubammad bin Ubaidillab menceritakan pada kami: Ibnu Abi Hąim menceritakan pada kami: Dari Al-Ala Dari Bapaknya : Dari Abu Hurairah radbiallabu'anbu, dia berkata, "Seseorang datang kepada Nabi shallallabu 'alaibi wasallam lalu berkata, "Wahai Rasulullab!, sesunggubnya aku memiliki kerabat yang aku jalin terus hubunganku dengan mereka, tapi mereka memutuskan bubungannya denganku, aku berbuat baik kepada mereka, tapi mereka berbuat jahat kepadaku. Mereka menyakitiku, tapi aku membalasnya dengan lemab lembut." Rasulullah 
menjawab, "Sekiranya kejadiannya seperti apa yang engkau katakan, maka engkau memberikan mereka bara api, sedangkan pertolongan Allah senantiasa menyertaimu atas mereka selama engkau berlaku seperti itu" (Abu Abdillah al-Bukhari, 2012, 24). Shahih, di dalam kitab As-Silsilah Ash-Shahihah (2597): (Muslim, 45- Kitab Al Birru wash-Shilatu wal Adab, hadits 22).

Hadis ini menjelaskan bagaimana seharusnya adab kita kepada kerabat yang memutuskan silaturrahim dengan kita, dan berbuat jahat ketika kita berbuat baik kepada mereka. Diceritakan bahwa seorang sahabat mengadukan kepada Rasulullah saw tentang kerabatnya yang memutuskan silaturrahim dengannya, dan membalaskan kebaikannya dengan kejahatan, kemudian Rasulullah bersabda jika benar seperti yang kamu katakana maka seolah-olah kamu member mereka makan dengan bara api. Imam An Nawawi menjelaskan bahwa perumpamaan ini membuat kerabatnya merasakan kepedihan karena orang yang berbuat baik itu tidak akan merugi. Akan tetapi kerabat yang memutuskan silaturrahim lah yang akan mendapatkan kerugian karena telah berbuat jahat dan memutuskan silaturrahim dengannya (Imam An Nawawi, 2010, 96).

\section{Hadis No. 101}

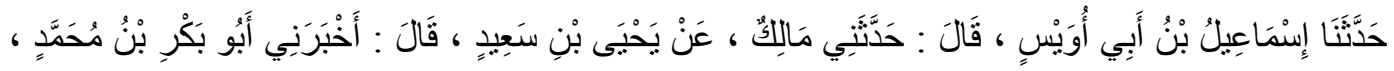

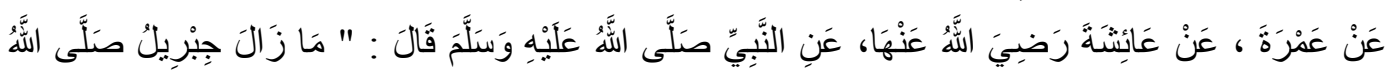

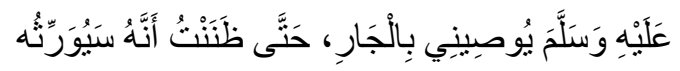

Ismail bin abu uwais menceritakan pada kami: Malik menceritakan padaku, dari Yabya bin Said: Abu Bakr bin Mubammad mengabarkan padaku, dari Amrah, Dari Aisyah radbiallahu 'anha, dari Nabi shallallabu 'alaibi wasallam bersabda, "Iibril tidak henti-hentinya berwasiat kepadaku agar (berbuat baik) kepada tetangga, sehingga aku mengira bahwasanya dia akan mewariskan tetangga itu" (Abu Abdillah al-Bukhari, 2012, 35). Shahih, di dalam kitab Al-Irwa (891). (Bukhari, 78, Kitab Al Adab, 28-Bab Al Wishatu Bil Jari. Muslim, 45Kitab Al Birru wash-Shilatu wal Adab, hadits 140)

Ibnu Hajar Al-Asqalany menjelaskan tetangga adalah orang yang berdekatan rumahnya dengan kita yang menyebabkan dia seperti saudara, dan hampir mendapatkan hak atas harta kita. yang menyebabkan tetangga itu ada dua hal, al mulashaqah (berdekatan rumah) dan al mukhalatah (bercampur), seperti satu mesjid, satu sekolah, satu pasar atau semisalnya. Tetangga mencakup muslim, kafir, orang 
rajin beribadah, orang fasik, orang jujur, musuh, orang asing, penduduk setempat, yang member manfa'at, yang member mudharat, orang yang dekat rumahnya ataupun jauh. Kemudian tanggung jawab untuk menyeru kepada Allah dan kesabaran akan berlipat ganda ketika tetangga kita adalah orang kafir atau fasik. Dan kisah Abdullah bin Umar yang mengahadiahkan seekor kambing kepada tetangganya yang beragama yahudi menguatkan pendapat ini (Husain bin Audah, 2003, 129).

\section{Hadis No. 353}

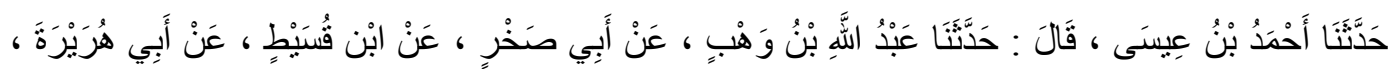

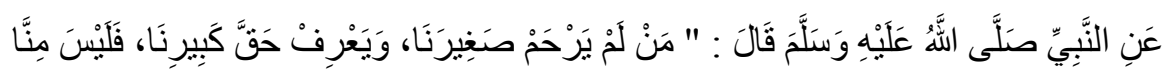
Abmad bin Isa menceritakan pada kami: Abdullah bin Wabb menceritakan pada kami: dari Abu Shakhri, dari Ibnu Qusaith, Dari Abu Hurairah, dari Nabi shallallabu 'alaibi wasallam bersabda, "Barang siapa tidak menyayangi anak kecil dan tidak mengetahui hak orang dewasa, maka dia bukan dari golongan kami" (Abu Abdillah al-Bukhari, 2012, 92). Shahih, di dalam kitab Shahihut-Targhib (1/117/97)

Ada dua hal yang sangat diperhatikan dalam Islam. Pertama, mengasihi dan menyangi anak karena mereka masih lemah, dan belum melakukan perbuatanperbuatan jelek, dan karena umurnya masih muda sehingga mereka bodoh, atau lalai maka disayangi dengan mengajarkann ilmu. Kedua, menghormati yang lebih tua. AlHakim menjelaskan bahwa memuliakan yang lebih tua karena hak dari umurnya yang telah beribadah kepada Allah dalam masa yang lama, dan menyayangi yang kecil karena dia tidak dibebani kewajiban beribadah (Al-Hakim, 1397, 41). Maka keduadua hal ini sangat penting. Ketika yang kecil diberikan haknya berupa kasih sayang dan kelembutan, maka yang tua juga diberikan haknya berupa kemuliaan dan keseganan.

\section{Hadis No. 521}

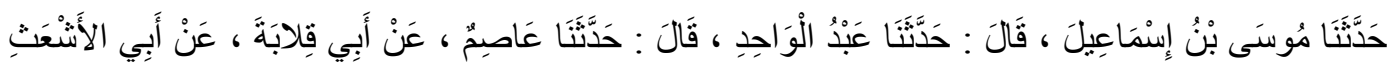

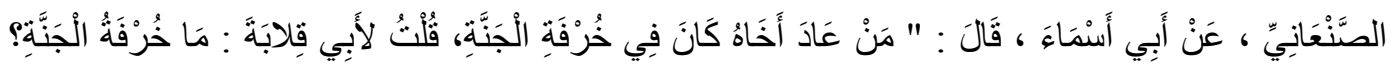

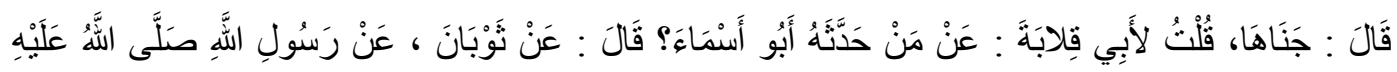


Musa bin Ismail menceritakan pada kami: Abdul Wabid menceritakan pada kami: Ashim menceritakan pada kami: dari Abu Qilabah, dari Abul Asy'ats Ash-Shan'ani, Dari Abu Asma' berkata, "Barang siapa membesuk saudaranya, maka dia berada pada khurafah surga." Saya berkata kepada Abu Qilabah, "Apa Khurfatul-Jannah itu?” Abu Qilabah menjawab, "Buah-buahan yang dipetik." Saya berkata kepada Abu Qilabah, "Dari siapa Abu Asma meriwayatkan haditsnya?" Abu Qilabah menjawab, "Dari Tsauban, dari Rasulullah shallallabu 'alaibi wasallam” (Abu Abdillah al-Bukhari, 2012, 130).

Hadis ini menjelaskan tentang keutamaan menjenguk orang sakit. Mengunjungi dan menjenguk orang sakit merupakan kewajiban setiap muslim, terutama yang memiliki hubungan dengan dirinya, seperti kerabat dekat, tetangga. Saudara yang senasab, sahabat dan lain sebagainya. Menjenguk orang sakit termasuk amal shalih yang paling utama, yang dapat mendekatkan kita kepada Allah swt, kepada ampunan, rahmat, dan surga-Nya. Mengunjungi orang sakit merupakan perbuatan mulia, dan terdapat keutamaan yang agung, serta pahala yang sangat besar, dan merupakan salah satu hak setiap muslim terhadap muslim lainnya. Ketika menjenguk saudara kita yang sakit, ada beberapa adab yang diajarkan oleh Rasulullah SAW seperti mendoakannya dengan doa yang telah diajarkan oleh beliau, bershalawat, dan adab-adab lainnya.

\section{Hadis No. 741}

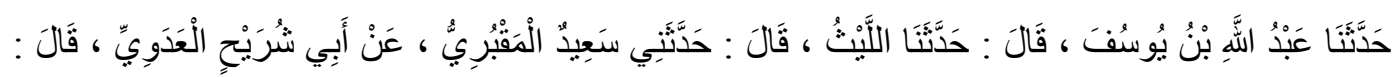

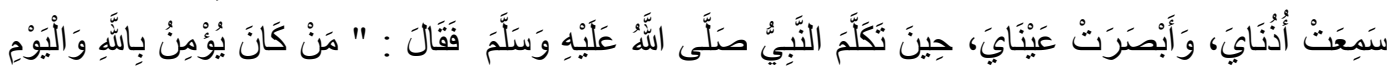

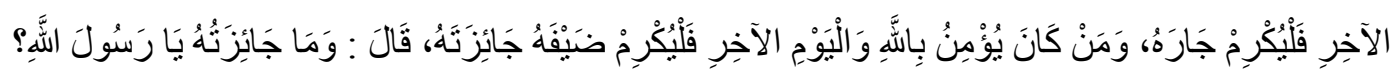

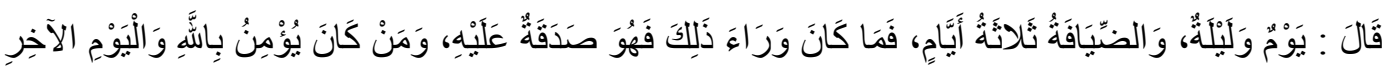

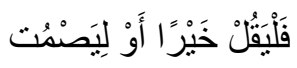

Abdullah bin Yusuf menceritakan pada kami: Laits menceritakan pada kami: Said Al-Maqburi menceritakan padaku: Abu Syuraih Al Adawi berkata, Aku mendengar dengan kedua telingaku, dan melibat dengan kedua mataku, Nabi Saw bersabda:"Barang siapa beriman kepada Allah Subhanahu wa Ta'ala dan hari akhir, maka hendaklah menghormati tetangganya, dan barang siapa beriman kepada Allah dan hari akhir hendaklah ia menghormati tamunya dengan memberikan hadiah." Rasulullah ditanya, apakah hadiah tersebut? Beliau menjawab, "Menjamunya sehari semalam dan memberikan hak tamu selama tiga hari, selebihnya adalah 
sadaqah, dan barang siapa beriman kepada Allah dan hari akhir hendaklah berkata dengan baik atau diam" (Abu Abdillah al-Bukhari, 2012, 182). Shahih, di dalam kitab Al Irwa (8/162/2523). (Bukhari, 78-Kitab Adab, 31- bab Man kaana yu'minu billah. Muslim, 1- Kitab Iman, hadits 77).

Hadis ini menerangkan adab dalam memuliakan tamu. Tamu dalam Islam memiliki kedudukan yang sangat terhormat. Umat Islam diperintahkan untuk memuliakan tamu sehingga menjadi tuntunan dan akhlak mulia. Imam Al-Qadhi Iyadh dalam memaknai hadis di atas menerangkan ketika umat berupaya menjalankan syari'at Islam, maka wajib baginya untuk memuliakan tetangga dan tamunya, serta berbuat baik kepada keduanya (Al-Qadhi Iyadh, 1998, 44). Dalam hadis ini juga dikaitkan perihal memuliakan tamu dengan kesempurnaan keimanan kepada Allah dan hari akhir. Ini adalah upaya menuju keimanan yang paripurna, mengingat beriman kepada Allah dan hari akhir merupakan bagian dari enam rukun iman yang wajib diyakini oleh segenap umat.

\section{Hadis No. 980}

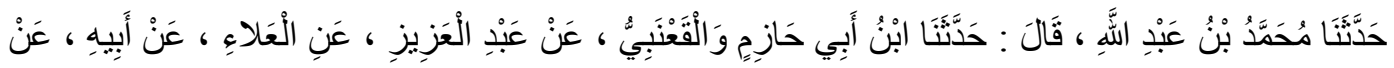

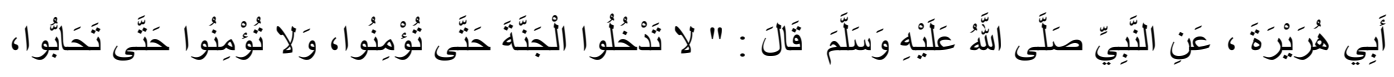

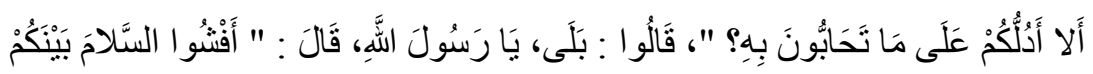

Mubammad bin Abdullah menceritakan pada kami: Ibnu Abu Hazim dan Al-Qa'nabi menceritakan pada kami, dari Abdul Aziঞ, dari Al-ala, dari Bapaknya: Dari Abu Hurairah radbiallabu 'anbu, dari Nabi shallallahu 'alaibi wasallam bersabda, "Kalian tidak akan masuk. surga sehingga beriman, dan tidaklah kalian beriman kecuali saling menyayangi. Maukah kalian Saya tunjukekan sesuatu yang dapat membuat kalian saling mencintai?" Mereka menjawab, "Ya, wahai Rasulullab!" Beliau bersabda, "Sebarkanlah salam di antara kalian" (Abu Abdillah alBukhari, 2012, 239).

Shahih, di dalam kitab Al-Irwa' (Muslim, 1- Kitab Al Iman, hadits 93).

Dalam hadis ini Rasulullah memberikan perhatian yang besar terhadap amalan salam, beliau memotivasi umatnya untuk senestiasa menanamkan dan mempraktekkan salam dalam kehidupan sehari-hari. Ath-Thiby mengatakan saling mengucapkan salam adalah sebab saling mencintai, dan cinta merupakan sebab 
sempurnanya keimanan dan meninggikan kata Islam, sedangkan saling tidak bertegur sapa, memutuskan silaturrahim terdapat perpecahan antara kaum muslimin yang menyebabkan rendahnya agama, dan kehinaan dalam Islam, dan menjadikan orangorang kafir lebih tinggi (Fathi bin Abdul Aziz, 2007, 207).

\section{Hadis No. 1056}

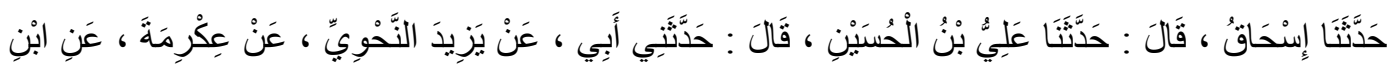

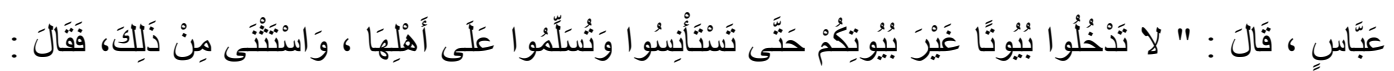

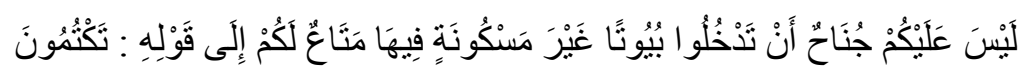
Ishaq menceritakan pada kami: Ali bin Husain menceritakan pada kami: Bapakeku menceritakan padaku: dari Yazid An-Nabwi, dari Ikrimah Dari Ibnu Abbas ia membaca "(Laa Tadkhulun Buyuntan Ghaira Buyuntikum Hattaa Tasta'nisun wa Tusallimun 'alaa Ablibaa)" [Qs. An-Nuur (24): 28], dan ia mengecualikan dari hal tersebut, lalu membaca, "Laisa 'Alaikum Junaahun An Tadkkulun Buyuntan Ghaira Maskunnatin fiihaa Mataa'un Lakum wallaabu Ya’lamu Maa Tubduuna wa Maa Taktumuun)" [An-Nuur (24): 29]( Abu Abdillah al-Bukhari, 2012, 257). Shahih sanadnya.

Hadis ini menjelaskan tentang meminta izin dan mengucapkan salam ketika kita ingin masuk ke rumah orang lain. Rumah pada hakikatnya adalah hijab bagi seseorang karena di dalamnya seseorang biasa membuka aurat. Di sana juga terdapat perkara-perkara yang ia malu apabila orang lain melihatnya. Oleh karena itu Rasulullah mengajarkan kepada kita untuk meminta izin sebelum memasuki rumah orang lain atau memasuki kamar dalam lingkup yang kecil. Syari'at Islam adalah syari'at yang universal. Tidak ada satupun perkara yang membawa kemaslahatan bagi kehidupan manusia kecuali Islam memerintahkannya. Dan tidak ada satupun perkara yang dapat membawa mudharat bagi kehidupan manusia kecuali Islam melarangnya. Tidak terkecuali dalam masalah adab meminta izin atau disebut isti'dzan. Meminta izin berbeda dengan ucapan salam, sebagaian orang beranggapan bila salam telah dijawab berarti dia boleh masuk ke dalam rumah tanpa harus meminta izin. Ini adalah anggapan yang keliru karena dalam hadis di atas membedakan antara salam dan minta izin. Dengan demikian, seorang yang telah dijawab salamnya harus meminta izin sebelum masuk ke dalam rumah. Dan inilah adab yang telah dicontohkan oleh Rasulullah saw (Hasan Ayyub, 1994, 56). 


\section{Adab Kepada Allah swt}

Adab kepada Allah merupakan tujuan yang tertinggi dalam pendidikan adab. Ketika seseorang sangat memperhatikan adabnya kepada Sang Khaliq, maka orang itu pasti sangat beradab kepada makhluk-Nya. Sebaliknya, ketika seseorang tidak memperhatikan adabnya kepada Allah, maka sudah pasti adabnya dalam kehidupan sehari-hari sangat kurang dan hampir dipastikan tidak ada karena adab yang utama tidak dia perhatikan. Imam Bukhari menjelaskan tentang adab-adab berdoa kepada Allah swt, di antaranya berdoa dengan hati yang khusyu', memulai doa dengan memuji Allah swt dan bershalawat kepada nabi, berdoa dengan penuh keyakinan bahwa Allah swt pasti akan mengabulkan setiap doa hambanya, mengangkat tangan ketika berdoa, tidak berdoa dengan mengaitkannya dengan iradat Allah seperti mengatakan "jika kamu ingin”, dan berdoa pada waktu-waktu dan tempat-tempat mustajab (Husain bin Audah, 2003, 253). Berikut hadis-hadis yang dikumpulkan Imam Bukhari tentang adab berdoa kepada Allah swt.

\section{Hadis No. 606}

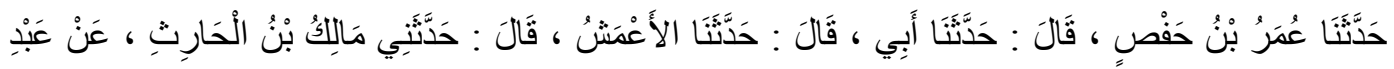

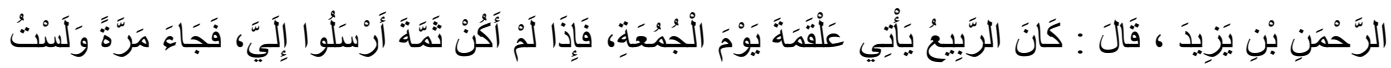

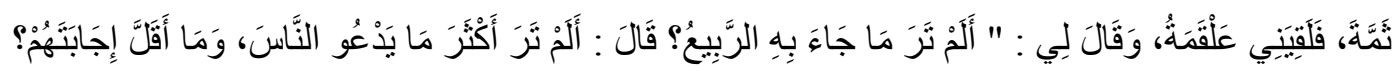

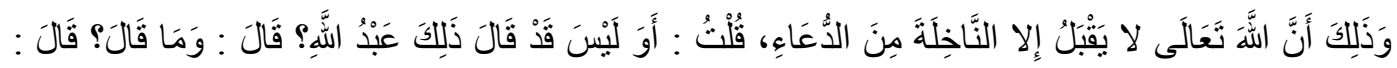

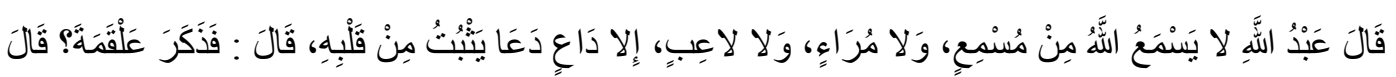

Umar bin Hafs menceritakan pada kami: Bapakku menceritakan padaku: Al-Amasy menceritakan padaku: Malik bin Harits menceritakan padaku: dari Abdur rabman ibnu Yazid berkata, "Ar-Rabi' mendatangi Alqamah pada hari jum'at. Apabila Saya tidak ada, mereka mengirim (utusan) kepada Saya. Suatu kali utusan itu datang, sedangkan Saya tidak ada. Kemudian Alqamah menemui Saya dan berkata, "Apakah engkau tidak melihat apa yang telah dibawa Ar-Rabi??" Alqamah berkata, "Apakah engkan tidak melihat sebanyak-banyak hal yang (diharapkan) manusia dalam berdoa, dan amat sedikit dari mereka dikabulkan (doanya)? Hal itu karena Allah Azza wa Jalla tidak akan menerima doa kecuali doa yang ikhlas." Saya berkata, "Bukankah Abdullah telah mengucapkan bal itu?" Alqamah berkata, "Apa yang diucapkan Abdullab?" Abdur rahman ibnu Yazid berkata," Abdullab berkata, "Allab tidak 
akan mendengar (doa) dari orang yang ingin dipuji orang lain, tidak pula dari orang yang riya", tidak pula dari orang yang bermain-main, akan tetapi (banya menerima doa) dari orang yang berdoa dengan keteguhan hatinya. "Abdurrahman bin Yazid berkata, "Lalu Alqamah ingat dan berkata, Ya” (Abu Abdillah al-Bukhari, 2012, 151). Shahih, sanadnya.

Dalam hadis ini dijelaskan tentang adab berdoa kepada Allah. Di sini disebutkan bahwa Allah tidak mendengarkan doa orang yang sum'ah, yaitu orang yang melakukan sebuah ibadah supaya didengar oleh manusia dan kemudian dia terkenal dengan ibadah tersebut. Allah juga tidak menerima doa orang-orang yang riya, yaitu orang yang menampakkan amal shalihnya kepada manusia supaya terlihat agung di mata manusia. Allah hanya menerima doa dari orang-orang yang berdoa dengan keteguhan hati, sebagaimana sabda nabi "Berdoalah kepada Allab dengan keyakinan bahwa Allah akan mengabulkan doamu, dan ketabuilah bahwa Allah tidak akan mengabulkan doa dari orang yang berbati lalai dan lengab” (Badru Ad Din, 2011, 120).

Imam Bukhari dalam Adab Al Mufrad meriwayatkan sebuah hadis yang mewajibkan bersungguh-sungguh dalam berdoa. Rasulullah saw bersabda "Apabila salab seorang di antara kalian berdoa, maka hendaklah dia bersunggub-sungguh dalam permohonannya kepada Allah dan janganlah ia berkata "Ya Allah, apabila engkau sudi maka kabulkanlah doa aku ini karena sesunggubnya tidak ada yang memaksa Allab" (Abu Abdillah al-Bukhari, 2012, 451). Maksud bersungguh-sungguh dalam berdoa adalah terus menerus dalam meminta dan memohon kepada Allah swt dan hal ini pasti tidak luput dari berbaik sangka kepada Allah bahwa Allah pasti mengabulkan doanya dan tidak mengaitkannya dengan kehendak Allah. Ibnu Hajar mengomentari bahwa yang dimaksud dengan mengaitkan doa dengan kehendak Allah supaya tidak terlihat memaksa Allah untuk mengabulkan doanya. Dan orang yang berdoa itu bermaksud bahwa dia tidak meminta sesuatu kecuali mengharap ridho Allah, sedangkan Allah sangat mengetahui isi hatinya, maka tidak ada faedah untuk mengaitkannya (Ibnu Hajar al Atsqalani, 2003, 291).

Mengangkat tangan ketika sedang berdoa juga termasuk adab berdoa kepada Allah swt dan merupakan hal yang disyari'atkan dalam Islam. Perbuatan merupakan adab dalam berdoa dan juga nilai tambah yang mendukung terkabulnya doa. Imam Bukhari dalam kitab Adab Al Mufrad meriwayatkan sebuah hadis dari Aisyah ra yang 
melihat nabi saw mengangkat kedua tangannya dan berdoa "Sesungguhnya Saya tidak lain adalah manusia, maka janganlah Engkau siksa Saya, dan siapapun dari orang mukmin yang Saya sakiti atau aku caci maki, maka janganlah Engkau menyiksa Saya karenanya”.

\section{Adab Kepada Nabi Muhammad saw}

Nabi Muhammad SAW adalah orang yang mengajarkan adab kepada umat Islam dan orang pertama yang mempraktekkan adab tersebut dalam kehidupannya sendiri. Sebagai seorang muslim yang beriman kepada Allah dan rasul-Nya tentu saja sangat memperhatikan adab kepada orang yang telah mengajarkannya adab itu sendiri. Imam Bukhari memulai pembahasan tentang adab kepada nabi Muhammad saw dengan sebuah hadis yang menjelaskan tentang kewajiban bershalawat kepada nabi ketika disebutkan namanya. Kewajiban untuk beradab kepada nabi Muhammad saw disebabkan oleh beberapa faktor yang telah dijelaskan di dalam Al-Qur'an. Pertama, dalam surat Al Hujarat ayat 1 Allah swt telah mewajibkan atas setiap muslim laki-laki dan perempuan untuk beradab kepada nabi Muhammad saw. Kedua, dalam surat Muhammad ayat 3 Allah swt telah mewajibkan atas orang mukmin untuk mentaati dan mencintai rasul-Nya. Ketiga, dalam surat An-Nisa' ayat 105 Allah telah menjadikan nabi Muhammad sebagai hakim dalam mengadili perkara yang terjadi antara manusia (Al-Qurthubi, 1964, 237). Dalam Adab Al-Mufrad Imam Bukhari hanya menjelaskan tentang kewajiban dan keutamaan bershalawat kepada nabi Muhammad saw dalam dua bab yang terdiri dari sembilan hadis:

\section{Hadis No. 644}

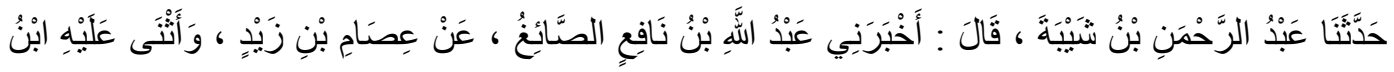

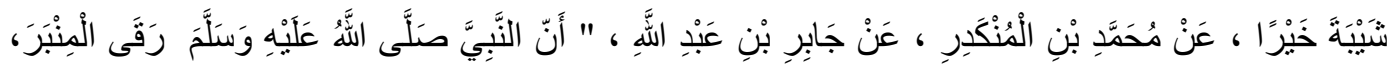

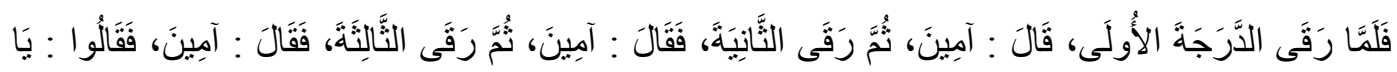

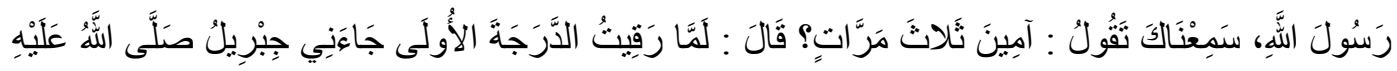

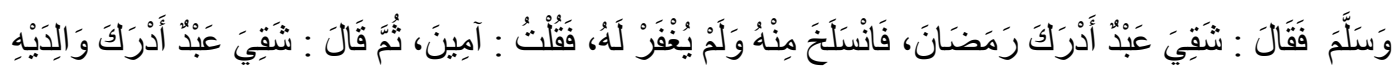

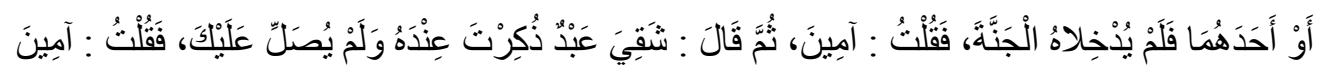
Abdrurabman bin Syaibah menceritakan pada kami: Abdullah bin Nafi' Ash-shaigh mengabarkan pada ku: dari Isham bin Zaid, dari Muhammad bin al-Munkadir, Dari Jabir bin Abdullah, Sesunggubnya Nabi shallallabu 'alaibi wasallam pernah naik mimbar, maka tatkala 
menaiki tangga yang pertama beliau berkata, “Aamïn”. Kemudian ketika menaiki tangga yang kedua beliau berkata, "Aamiin”, lalu ketika menaiki tangga yang ketiga beliau berkata, "Aamïn”, maka mereka berkata, "Wahai Rasulullab! Kami telah mendengar engkau berkata, "Aamiin" tiga kali." Nabi bersabda, "Tatkala Saya menaiki tangga yang pertama maka datanglah Jibril 'alaihissallam lalu berkata, "Celakalah seorang hamba yang mendapatkan bulan Ramadhan lalu dia meninggalkannya sedangkan dia tidak memohon ampun" lalu Saya berkata, "Aamiin." Kemudian (Jibril) berkata, "Celakalah seorang hamba yang mendapati orang tuanya atau salah satunya (dalam keadaan tua), tapi tidak dapat masuke ke dalam surga (karena tidak berbakti)." Lalu Saya berkata, "Aamïn." Kemudian dia (Jibril) berkata, "Celakalah seorang hamba yang namamu disebut di sisinya tapi dia tidak membacakan shalawat kepadamu." Lalu saya berkata, "Aamiin" (Abu Abdillah al-Bukhari, 2012, 159). Shahih lighairihi di dalam kitab At-Ta'liq Ar Raghibu (2/283).

Hadis ini menjelaskan salah satu adab kita kepada Rasulullah saw, yaitu bershalawat ketika kita mendengar nama beliau. Husain bin Audah menjelaskan bahwa hadis ini adalah salah satu dalil yang mewajibkan bershalawat kepada nabi Muhammad saw ketika kita mendengar namanya. Dan bershalawat kepada nabi bisa mendatangkan kebahagiaan karena orang yang bershalawat dalam mentauhidkan Allah swt dan mengikuti nabi dengan sebaik-baiknya (Husain bin Audah, 2003, 301).

Sesungguhnya bershalawat kepada nabi telah diperintahkan oleh Allah swt dalam surat Al-Ahzab ayat 56: "Wahai orang-orang yang beriman, bershalawatlab kamu untuk Nabi, dan ucapkanlah salam dengan penuh penghormatan kepadanya" (Departemen Agama RI, 2012, 426). Dalam ayat ini juga disebutkan bahwa Allahswt dan malaikatnya juga bershalawat kepada nabi Muhammad saw. Selain merupakan bentuk adab kepada Rasulullah ketika kita mendengar namanya, bershalawat kepada beliau juga memiliki banyak keutamaan, diantaranya adalah mendapatkan sepuluh pujian dari Allah swt, ini sesuai dengan hadis yang diriwayatkan oleh Abu Hurairah ra, Rasulullah saw bersabda, "Siapa yang mengucapkan shalawat kepadaku satu kali, maka Allah mengucapkan shalawat kepadanya sebanyak sepulub kali". Maksud dari Allah swt bershalawat atas seorang hamba tersebut adalah bahwa Allah swt akan memuji hamba itu di hadapan para malaikatnya sebanyak sepuluh kali pujian (Ibnu Katsir, $1419 \mathrm{H}, 94)$. 


\section{Relevansi Pendidikan Adab dalam Kitab Adab Al Mufrad Karya Imam Bukhari Terhadap Pendidikan Karakter di Indonesia}

Dari uraian hadis di atas dapat dilihat pemikiran Imam Bukhari tentang adab yang meliputi adab kepada orang tua, adab kepada anak, adab kepada sesama, adab berdoa kepada Allah swt, dan adab kepada nabi Muhammad saw. Adab-adab tersebut memiliki hubungan dengan pilar-pilar nilai pendidikan karakter di Indonesia. Berdasarkan kajian nilai-nilai agama, norma-norma sosial, peraturan/hukum, etika akademik, da prinsip-prinsip HAM, telah teridentifikasi 80 butir nilai karakter yang dikelompokkan menjadi lima, yaitu; (1) nilai-nilai perilaku manusia dalam hubungannya dengan Tuhan Yang Maha Esa, (2) nilai-nilai perilaku manusia dalam hubungannya dengan dirinya sendiri, (3) nilai-nilai perilaku manusia dalam hubungannya dengan sesama manusia, dan (4) nilai-nilai perilaku manusia dalam hubungannya dengan lingkungan, serta (5) nilai-nilai perilaku manusia dalam hubungannya dengan kebangsaan (Ibnu Katsir, 1419 H, 94). Konsep pendidikan adab Imam Bukhari dalam kitab Adab Al-Mufrad memiliki beberapa kaitan dengan pilar-pilar nilai pendidikan karakter di Indonesia. Berikut adalah uraiannya:

\section{Nilai karakter terhadap Tuhan Yang Maha Esa}

Kemendiknas mengaitkan nilai karakter manusia dalam hubungannya dengan Tuhan Yang Maha Esa pada pikiran, perkataan, dan tindakan seseorang yang diupayakan selalu berdasarkan pada nilai-nilai ketuhanan dan/ ajaran agamanya (Ibnu Katsir, 1419 H, 33). Bagi seorang muslim, yang menjadi landasan dan dasar dia dalam berfikir, berbicara dan bertindak adalah Al-Qur'an dan hadis. Maka ketika kita perhatikan pada konsep pendidikan adab Imam Bukhari selalu berlandaskan firman Allah swt dan sabda nabi Muhammad saw. Konsep berbuat baik dan beradab kepada orang tua berasal dari perintah Allah swt yang mewajibkan untuk berbakti kepada kedua orang tua.

Sama halnya dengan berbuat baik kepada anak yang juga berasal dari sabda nabi yang memerintahkan untuk memenuhi hak-hak dan kebutuhan anak akan tempat berlindung, pakaian dan ilmu pengetahuan. Kemudian menyambung silaturrahim, berbuat baik kepada tetangga, menjenguk orang sakit, dan menghormati tamu juga berasal dari perintah nabi dan langsung beliau praktekkan dalam kehidupan 
beliau sendiri. Begitu juga adab berdoa kepada Allah swt dengan hati yang khusyuk, ikhlas, mengangkat kedua tangan, dan yakin bahwa Allah swt Maha Mendengar doa hamba-hamba-Nya (Abu Abdillah al-Bukhari, 2012, 151). Dari sini dapat kita lihat bahwa setiap pikiran, perkataan, dan perbuatan dalam konsep pendidikan adab Imam Bukhari harus berdasarkan perintah Allah swt.

\section{Nilai karakter dengan diri sendiri}

Nilai karakter dalam hubungannya dengan diri sendiri meliputi sikap jujur, yaitu upaya untuk menjadikan dirinya sebagai orang yang selalu dapat dipercaya dalam perkataan, tindakan, dan pekerjaan baik terhadap diri sendiri maupunpun orang lain. Bertanggung jawab, melaksanakan tugas dan kewajiban sebagaimana seharusnya, terhadap diri sendiri, masyarakat, lingkungan, Negara, dan Tuhan Yang Maha Esa. Bergaya hidup sehat dengan menerapkan kebiasaan yang baik dalam menciptakan hidup yang sehat dan menghindari kebiasaan buruk yang dapat mengganggu kesehatan. Disiplin, tertib dan patuh pada berbagai peraturan dan ketentuan. Kerja keras dengan menunjukkan upaya sungguh-sungguh dalam mengatasi berbagai hambatan guna menyelesaikan permasalahan dengan sebaik-baiknya. Percaya diri dengan kemampuan sendiri untuk mencapai setiap keinginan. Berjiwa wirausaha, berfikir logis, kritis, kreatif, dan inovatif. Mandiri, yaitu sikap dan perilaku yang tidak mudah bergantung pada orang lain dalam menyelesaikan masalah. Ingin tahu dan cinta ilmu, selalu berupaya untuk mengetahui lebih dalam dan meluas dari apa yang telah dipelajari, dilihat, dan didengar (Abu Abdillah al-Bukhari, 2012, 151).

Secara garis besar hampir tidak bisa dilihat kaitan konsep pendidikan adab Imam Bukhari dengan nilai karakter kepada diri sendiri. Namun Allah swt berfirman dalam surat Al-Isra' ayat 7: 'Jika kamu berbuat baik (berarti) kamu berbuat baik untuk dirimu sendiri. Dan jika kamu berbuat jahat, maka (kerugian kejahatan)itu untuk dirimu sendir”" (Departemen Agama RI, 2012, 282). Dari ayat ini dapat kita fahami bahwa pendidikan adab Imam Bukhari memliki kaitan yang erat dengan pilar-pilar nilai pendidikan karakter di Indonesia. Ketika seseorang berbuat baik kepada orang tua, berbuat baik kepada anak, dan berbuat baik kepada sesama maka ketika itu juga dia sedang berbuat baik pada dirinya sendiri. 


\section{Nilai karakter dengan sesama}

Nilai karakter dalam hubungannya dengan sesama meliputi kesadaran akan hak dan kewajiban diri dan orang lain, dan melaksanakan apa yang menjadi milik/ hak diri sendiri dan orang lain serta tugas/ kewajiban diri sendiri dan orang lain. Kemudian patuh pada aturan-aturan sosial yang berkenaan dengan masyarakat dan kepentingan umum. Menhargai karya dan prestasi orang lain dengan tujuan untuk mendorong diri sendiri dalam menghasilkan sesuatu yang berguna bagi masyarakat. Santun, halus dan baik dari sudut pandang tata bahasa maupun tata perilakunya kepada semua orang. Terakhir, demokratis dalam berfikir dan bertindak dengan menyamakan hak dan kewajiban seperti orang lain (Heri Gunawan, 2015, 33).

Konsep pendidikan adab kepada sesama menurut Imam Bukhari memliki kesamaan dengan pilar nilai karakter kepada sesama. Adab kepada sesama menurut Imam Bukhari adalah adab kepada sesama makhluk, baik sesama manusia, hewan, tumbuhan, dan lingkungan. Ada beberapa poin adab kepada sesama makhluk yang harus diperhatikan. Di antaranya, menjaga silaturrahim, berbuat baik kepada tetangga, berbuat baik kepada budak, saling memaafkan, saling berbagi, memuliakan yang tua dan menyayangi yang lebih muda, menyayangi hewan, membesuk orang sakit, memuliakan tamu dan memberikan hak-haknya, berbicara dengan perkataan yang baik, optimis dalam kehidupan, saling mengucapkan salam, memnita izin untuk memasuki rumah atau kamar, dan banyak lagi adab-adab lainnya terhadap sesama (Husain bin Audah, 2003, 9).

Dari pendidikan adab kepada sesama menurut Imam Bukhari, menjaga silaturrahim, berbuat baik kepada tetangga, saling berbagi dan memaafkan, optimisme dalam kehidupan, saling mengucapkan salam, dan menghormati yang tua menyayangi yang muda terdapat di dalamnya nilai karakter kepada Allah swt karena semua adab kepada sesama berdasarkan perintah-Nya. Kemudian juga terdapat pengembangan karakter dermawan, tolong menolong, hormat menghormati, keadilan toleransi, kedamaian dan kesatuan yang merupakan bentuk dari adab kepada sesama. Menurut Imam Bukhari, adab kepada sesama harus dilakukan dari lingkungan terdekat seperti kedua orang tua, anak, tetangga, atau sahabat-sahabat terdekat, kemudian terhadap lingkungan masyarakat yang lebih luas. 


\section{Nilai karakter dengan lingkungan}

Nilai karakter dalam hubungannya dengan lingkungan adalah sikap dan tindakan yang selalu berupaya mencegah kerusakan pada lingkungan alam di sekitarnya, dan mengembangkan upaya-upaya untuk memperbaiki kerusakan alam yang sudah terjadi dan selalu ingin memberi bantuan bagi masyarakat dan orang yang membutuhkan (Husain bin Audah, 2003, 9).

Dalam kitab Adab Al-Mufrad Imam Bukhari menjelaskan tentang berbuat baik kepada hewan, memelihara dan merawat tumbuhan dan bangunan. Dalam sebuah hadis dikisahkan bahwa seorang pemuda yang masuk surga karena telah member minum seekor anjing yang sedang kehausan (Abu Abdillah al-Bukhari, 2012, 97). Kemudian juga hadis yang menceritakan tentang rasulullah saw yang sedang memperbaiki dinding dan membangunnya kembali (Abu Abdillah al-Bukhari, 2012, 113). Maka dapat kita lihat bahwa pendidikan adab Imam Bukhari memliki kaitan dengan karakter terhadap lingkungan yang sangat memperhatikan keadaan lingkungan sekitar.

\section{Nilai karakter dengan kebangsaan}

Nilai karakter dalam hubungannya dengan kebangsaan adalah dengan berfikir danbertindak dengan menempatkan kepentingan bangsa dan Negara di atas kepentingan diri dan kelompoknya. Hal ini meliputi sikap nasionalis yang berfikir dan bertindak yang menunjukkan kesetiaan, kepedulian, dan penghargaan yang tinggi terhadap bahasa, lingkungan fisik, social, budaya, ekonomi dan politik bangsa. Kemudian menghargai keberagaman, memberikan sikap respek dan rasa hormat terhadap berbagai macam hal baik yang berbentuk fisik, sifat, adat, budaya, suku, dan agama (Heri Gunawan, 2015, 33).

Untuk membentuk karakter kebangsaan, maka yang harus diperhatikan lebih dahulu menurut Imam Bukhari adalah pendidikan adab dalam keluarga, adab anak kepada orang tua, dan adab orang tua kepada anak, serta adab kepada sesama. Karena untuk menciptakan bangsa yang berkarakter harus diperbaiki dari komponen terkecil dari sebuah bangsa, yaitu keluarga. Dengan terbentuknya keluarga-keluarga yang berkarakter, maka akan terbentuk pula masyarakat yang berkarakter, dan dengan 
terbentuknya masyarakat yang berkarakter akan terbentuk sebuah bangsa yang maju, kuat, dan berkarakter.

\section{KESIMPULAN}

Melalui penelaahan dan penelitian terhadap kitab Adab Al Mufrad karya Imam Bukhari dan relevansinya dengan pendidikan karakter di Indonesia, maka dapat ditarik kesimpulan bahwa pendidikan adab menurut Imam Bukhari adalah seseorang beradab kepada orang tua, kepada anak, dan kepada sesama sesuai dengan perintah Allah swt dan sesuai dengan yang telah dicontohkan oleh Rasulullah saw. Kemudian seseorang beradab ketika berdoa kepada Allah swt dengan hati yang ikhlas dan khusyuk dan penuh keyakinan bahwa Allah akan mengabulkan doanya. Dan dari bentuk adab kepada nabi Muhammad saw adalah bershalawat kepada beliau, ketika disebutkan namanya.

Relevansi pendidikan adab menurut Imam Bukhari dengan pendidikan karakter di Indonesia bahwa pendidikan karakter yang dilaksanakan di Indonesia dikembangkan dari nilai-nilai yang berlaku di masyarakat, salah satunya adalah nilainilai yang bersumber dari ajaran agama. Pendidikan adab menurut Imam Bukhari yang bersumber dari hadis-hadis Rasulullah saw dan atsar-atsar dari sahabat dan tabi'in akan sangat relevan untuk dijadikan sebagai dasar untuk memperkuat pendidikan karakter di Indonesia.

\section{DAFTAR PUSTAKA}

Abdussalam, Suroso. 2011. Sistem Pendidikan Islam. Bekasi: Sukses Publisher.

Abu Syuhbah, Muhammad. 1981. Fi Ribab al Sunnah al Kutub As Shibhah al Sittah. Kairo: Majma' al Buhuts al Islamiyah.

Al Atsary, 2007, Birrul Walidain (Berbakti Kepada Kedua Orang Tua), Jakarta: Pustaka Imam Syafi'I.

Al Baghdadi. 1992. Al Fiker al Tarbawi 'Inda al Hatib al Baghdadi. Beirut: Dar al Hair.

Al Jailani, Fadhlullah. 1364 H. Fadhlullahis Shamad fi Taudhibil Adabil Mufrad. Kairo: Maktab as Salafiyah.

Al Jauzy, Ibnu. 1985. Shifatus Shafwah. Beirut: Dar al Ma'rifah. 
An Nahlawi, Abdurrahman. 1995. Pendidikan Islam di Rumah, Sekolah, dan Masyarakat, Jakarta: Gema Insani Press.

Bin Audah, Husain. 2003. Syarah Shabih Adabul Mufrad. Beirut: Maktab al Islamiyah.

Bukhari, Abu Abdillah. 2012. Shahih Bukhari. Beirut: Dar at Taashil.

Gunawan, Heri, 2012, Pendidikan Karakter Konsep dan Implementasi. (Bandung: Alfabeta,

Hamka, Abdul Aziz, 2011, Pendidikan Karakter Berpusat pada Hati, Jakarta: al-Mawardi,. Hasbullah, 2009, Dasar-dasar Ilmu Pendidikan, Jakarta: Raja Grafindo Persada.

Hidayat, Syarif. "Pendidikan Berbasis Adab Menurut A. Hassan". Jurnal Pendidikan Agama Islam. Vol. XV, No. 1, Juni 2018. Bogor: Universitas Ibnu Khaldun.

Judiani, Sri Implementasi Pendidikan Karakter Di Sekolah Dasar Melalui Penguatan Pelaksaan Kurikulum, Jurnal Pendidikan Dan Kebudayaan, (Jakarta: Balitbang Kemendiknas, vol. 16 Edisi Khusus III, Oktober 2010)

Muhidin, Ihsan., Ulil Amri Syafri. "Metode Pendidikan Akhlak dalam Kitab Adab Almufrad Karya Imam Bukhari”. Misykat al Anwar. Jurnal.fai.-umj.ac.id. 2012. Bogor: Universitas Ibnu Khaldun.

Nurdin, Indra Fajar. "Perbandingan Konsep Adab Menurut Ibnu Hajar al Asqalany dengan Konsep Pendidikan Karakter di Indonesia". Jurnal Pendidikan Islam Vol. IV, No.1, Juni 2015/1436. Yogyakarta: UIN Sunan Kalijaga.

Pijaki Nufus, Fika, dkk, Konsep Pendidikan Birrul Walidain dalam QS. Luqman Ayat 14 dan Al Isra Ayat 23-24. Jurnal Ilmiah DIDAKTIKA, Vol. 18 No. 1, Agustus 2017

Syafri, Ulil Amri, Pendidikan Akblak dalam Perspektif Al Qur'an, Jurnal Ta'dibuna, Vol 1 2011, Bogor: Universitas Ibnu Khaldun. 